\title{
The revitalization of Northeast China economy must start with institutional innovations
}

\author{
XU Jiang \\ (School of Economy, Wuhan University of Technology, Wuhan 430070, China)
}

\begin{abstract}
Starting with the basic knowledge of the system, the researcher analyzes the significance of institutional innovation in revitalizing old industrial bases in Northeast of China. It is not difficult to discover that Northeast's backwardness is caused by both of the historical and the artificial reasons. What's more, owing to the establishment of market economy, the old system no longer satisfies the development of the new system. Therefore, in order to speed up the Northeast region's economy and make it truly become the fourth growth pole, we must accelerate the innovation system.
\end{abstract}

Key words: institutional innovation; revitalizing Northeast China; the fourth growth pole

System innovation is an alternative process in which a system is substituted by another more efficient system. The core of China's reform and opening-up policy is, in the framework of the socialistic institution, to reconstruct the rules of the game, make out the new institutional arrangement in accordance with the principle of market economy, and promote the economic development and social progress. So, the key of the system innovation lies in the establishment of the market mechanism and improvement of the market level, therefore, to promote the development of the northeast region, we have to continuously deepen the reform of the market economy, speed up institutional innovation, and establish a market mechanism which is conducive to the effective operation of the system structure.

\section{The significance of speeding up the institutional innovation of Northeast old industrial base}

The so-called old industrial base refers to the industrial region which has formed in the long-term process of the industrial development, has made the tremendous influence and the contribution to the regional or the national economy, but presents the relative decline in the new time. Northeast old industrial base has the rich natural resource, for instance, the agriculture, the forest, and the minerals, which are indispensable to the economic development, and also has the very good industrial foundation and the transportation superiority. In addition, it is close to Russia, North Korea, Japan and Mongolia, besides, the condition of its development are advantageous because of the new Europe and Asia continental bridge. However, since the reform and opening-up, the Northeast area's economic status actually has been unceasingly dropping, the business economic benefit is worse, and the unemployment problem becomes increasingly serious. Not only does it has affected the local economic development, but also has restricted the national economic development. Therefore, revitalizing the Northeast is significant to the national economic development.

Since the reform and opening up, the institutional innovation has become the main impetus to promote the economic growth of our country. But compared with Eastern coastal province, the institutional innovation of Northeast old Industrial base has obviously lagged far behind. During the "11th Five-Year Plan” period, premier

XU Jiang, senior accountant, Ph.D. candidate of School of Economy, Wuhan University of Technology; research field: industrial economics. 
WEN Jia-bao made important instructions of finding out news ways to revitalize old industrial base with new ideas, new systems, new mechanisms and new methods in Changchun forum. The substance of premier WEN's speech is clear, that is, to revitalize the old northeast industrial base, system and mechanism innovation must advance first, and system innovation strategies must be implemented.

\section{Analysis on the system of old industrial base}

\subsection{Analysis on institution economics}

(1) The compulsory system change is weak. The goal of the state-owned enterprise is to establish the modern enterprise system, to realize the separation of the rights of management and property rights, to form the multiplex structure of system ownership, and to enhance the vigor, the power and the efficiency of the enterprises.

(2) Effective system supply shortage. The most outstanding issue which put the old industrial bases in northeast of China through the plight is that the state-owned economy takes exceedingly high proportion. Therefore, the country should adopt various institutional arrangements to quickly shrink the state-owned economic battlefront, strategically adjust the state-owned economy and restructure the state-owned enterprises.

(3) The traditional system accumulation is excessive. In the planned economy period, the Northeast old industrial base is the cradle of national equipment industry. But the comprehensive implementation of planned economy system in Northeast caused the huge resistance, the poor effect, and excessively high cost when the market economy system entered.

\subsection{Market analysis}

China has made impressive economic progress since the reform and opening up in the past 30 years, not only does the fundamental reason lie in technological innovation, but more important ones also lie in implementing the institutional innovation of market-oriented reform on the traditional system of planned economy. Regarding the most countries and areas in the world, there is relatively obvious mutual promotion relationship between the marketization and the level of economic development. The higher the marketization degree is, the faster the economic development is. The imbalance of the regional development, from the system aspect, is caused by the different degrees of market-oriented system innovation. Therefore, the basic reason for the northeast old industrial base falling behind should be sought from the level of marketization and institutional innovation.

\subsection{Several concrete analysis on actors}

(1) State-owned enterprise reform is very difficult and the cost of system changes is very high. Northeast state-owned economy is large in scale, the level of the private economy is high, and the private economy is relatively weak.

(2) The pressure from interest groups. No matter from economical or historical perspective, the existing vested interests are the one who always hinder the system vicissitude. Most of the Northeast of China's state-owned economic system formed in the period of the traditional economic structure, by the time because of the impact of domestic and international environment, China's investment and policies are tilted to the Northeast, resulting in the northeast state-owned system accumulated significantly high, and formed a large number of interest groups.

(3) Non-healthy factor disturbance from the government. Some government functional departments and some individuals make use of the state economy to make rent-seeking. The state-owned business and the government have the very complicated relations, besides the tax revenue relations, they also have the profit relations, the executive position arrangement relations and so on, the government officials precisely use the government and enterprise's profit to negotiate, make rent-seeking depending on whether the executive position is arranged, therefore, in a sense, the state-owned business is economic basis of rent-seeking and the corruption. 


\section{Several suggestions on the institutional innovation of the Northeast old industrial base}

\subsection{The premise of the institutional innovation is transforming ideas}

Firstly, the government of all levels in the Northeast area must change their concepts, never want to control anything again. Instead, set up "the management is service" as the concept required by the market economy to create an optimized policy environment for the local economic development and provide for the enterprises the good space in which they can operate independently. Secondly, the state-owned business must transform the dependent mentality, establish the concept of market competition, seek the chance of business development in the market, rather than rely on the government to give the consideration. At last, individuals must break the thought of a lifelong secure job, set up the concept of independent profession choice and starting an undertaking to bring up the capability of adapting the market and the employment view required by the market.

3.2 Eternal forces are introduced and the system locking of the Northeast old industrial bases are broken

North has pointed out that to reverse the path dependence and highlight the original state of the system locking; we must use external effects and introduce the exogenous variables or rely on the regime change. It is necessary to forcibly implant into a new system and technology from the outside world in the process of development and gradually become endogenous.

\subsection{We must actively support the non-state economy development}

The non-state economy development is slow, and it is another significant reason for the low level of marketization of the Northeast old industrial base. To accelerate the marketization process of the northeast region, we should actively support the development of the non-state economy. We should set up the correct concept of private enterprise development, correctly regard the status and function of private economy; enlarge the financial support towards the private enterprise, and establish many kinds of channels which provides the financing service for the private enterprise; through creating the loose environment of development, we will break the trade monopoly and the system of ownership discrimination, implement more open admittance policy of trade investment and expand the domain the private economy will enter.

\section{Conclusion}

The primary task for the northeast of China is not taking the new way to industrialization, but based on their own, speeding up the new system innovation, achieving the fundamental change from the planned economic system to the market economic system as soon as possible, particularly solving the problems of the government's functions and the reform of state enterprises. With the implementation of "the 11th Five-Year Plan", from the Party Central Committee and the State Council and down to people, all have paid close attention to the revitalization of northeast of China. As long as the northeast region firmly seize the historical opportunity, it is not impossible to become the fourth growth pole of the China's economy.

\section{References:}

CHEN Tian-xiang. (2004). An explanation of the role of China's local government's insititutional innovation. Journal of Zhongshan University: Social Sciences, (4).

CHEN Wen-hui. (2006). Underdeveloped regions' economic evitalization road. Beijing: The Social Sciences Literature Publishing House.

CHEN Xiu-shan. (2005). China regional economic research. Beijing: The Commercial Press.

FU Yong. (2006). The insititutional analysis China's regional economic cooperation. In Reform and Strategy (Nanning), (2).

LU Xian-xiang. (2004). New institutional economics.Wuhan: Wuhan University Press.

(Edited by Emily and Joy) 